\title{
A Test of Dividend Policy: The Case of the Japanese Machinery Industry Firms
}

\author{
Chikashi TSUJI \\ Graduate School of Systems and Information Engineering, University of Tsukuba \\ 1-1-1 Tennodai, Tsukuba, Ibaraki, Japan \\ E-mail: mail_sec_low@minos.ocn.ne.jp
}

Received: April 28, $2011 \quad$ Accepted: May 17, $2011 \quad$ doi:10.5539/ijef.v3n3p119

The author thanks the Japan Society for the Promotion of Science, the Zengin Foundation for Studies on Economics and Finance, Nihon Housei Gakkai, and the Japan Securities Scholarship Foundation for their generous financial assistance for this research. I also greatly thank the Editor and anonymous referees for constructive comments to this paper.

\begin{abstract}
This paper comprehensively explores the determinants of the dividend policy of the Japanese machinery industry corporations. First, our empirical examinations clarify that in this industry, corporate managers do not cater to investors' dividend demand in both their dividend initiation and continuation decisions. Instead, in the Japanese machinery industry, the significant determinants of firms' dividend initiations are value-weighted payers' and nonpayers' market-to-book ratio, value-weighted all companies' dividend yields, value-weighted nonpayers' size, and nonpayers' value-weighted after-tax earnings-to-total-asset ratios in the previous year. Moreover, in this industry, the significant determinants of firms' dividend continuations are value-weighted all companies' market-to-book ratio, value-weighted payers' market-to-book ratio, value-weighted all companies' dividend yields and size, and payers' value-weighted size in the previous year.
\end{abstract}

Keywords: Catering theory of dividends, Dividend policy, Imperfect market, Inefficient market, Signaling hypothesis.

\section{Introduction}

Classic study of Miller and Modigliani (MM) (1961) proved that dividend policy is irrelevant to share value in efficient and perfect capital markets. After the proof, many academic researchers discussed and criticized it using different approaches. (Note 1)

Recently, Baker and Wurgler (BW) (2004a) developed a new interesting theory, which is called the "catering theory of dividends". (Note 2) Relaxing the assumption of efficient and perfect capital markets (Note 3) assumed in MM (1961), and considering behavioral characteristics, BW (2004a) suggested as follows by building a simple theoretical model. First, some investors possess an uninformed demand for dividend-paying stocks, and this demand may be time-varying. Next, arbitrage fails to prevent this demand from driving apart the values of dividend payers and nonpayers. Third, corporate managers rationally cater to this investors' demand-they pay dividends during investors put higher prices on dividend payers, and they do not pay during investors prefer nonpayers.

As far as we know, this new theory has not been tested by focusing the case of Japan; hence, testing catering theory using Japanese data is one of our objectives in this paper. More precisely, we examine the catering theory of dividends by focusing on the Japanese machinery industry, which is one of the most important industries in Japan. In addition, comprehensively extending BW's (2004a) investigations, we further explore the determinants of the dividend policies of the Japanese machinery industry corporations from the viewpoints of cross-sectional and aggregate time-series.

The findings derived in this paper are as follows. First, as to the dividend initiations and continuations for the Japanese machinery industry firms, the dividend premium is not a determinant. This implies that these firms in Japan do not behave as predicted by catering theory.

Second, differently from the US case, value-weighted payers' and nonpayers' market-to-book ratio, value-weighted all companies' dividend yields, value-weighted nonpayers' size, and nonpayers' value-weighted after-tax earnings-to-total-asset ratios are the significant determinants of one-year-ahead dividend initiations in the Japanese machinery industry firms. 
Third, contrary to the US case, value-weighted all companies' market-to-book ratio, value-weighted payers' market-to-book ratio, value-weighted all companies' dividend yields and size, and payers' value-weighted size are the singnificant determinants of one-year-ahead dividend continuations in the Japanese machinery industry firms.

Fourth, from a cross-sectional viewpoint, we find a relation between corporate earnings and firm dividend decisions; however, we find that earnings conditions are best in the year before firms pay dividends, and we also find that earnings conditions are second best in the year they are dividend payers and worst in the year after firms pay dividends. We consider that this evidence does not support the signaling hypothesis.

The rest of the paper is organized as follows. Section 2 introduces BW's (2004a) catering theory of dividends and explains our research design, Section 3 describes the data, Sections 4 and 5 demonstrate the empirical results, and Section 6 summarizes the paper.

\section{Theory and research design}

We examine the catering theory and then extend the research of BW (2004a). The catering theory of dividends by BW (2004a) suggested that real capital markets are inefficient and imperfect, and corporate managers make their dividend initiation and continuation decisions by catering for the investors' dividend demand. Typically, as in BW (2004a), the investors' dividend demand can be captured by the difference between dividend payers' M/Bs and nonpayers' $\mathrm{M} / \mathrm{Bs}$, which corporate managers are able to observe through financial markets. Hence, the catering theory of BW (2004a) predicts that when the dividend payers' M/Bs are higher than the nonpayers' M/Bs, corporate managers make dividend initiations or dividend continuations by catering for the investors' demand for dividends.

In this paper, after examining this catering theory, we extend BW's (2004a) researches. More precisely, we comprehensively explore the determinants of dividend initiations and continuations in the Japanese machinery industry firms by adding many variables and by using both cross-sectional and aggregate time-series analysis.

\section{Data}

First, we construct dividend payment measures by following BW (2004a). All data used in this paper are supplied by QUICK Corp. The full sample period in this study is from 1986 to 2006, and our study focuses on the machinery industry firms in Japan. As at the end of December 2009, the NIKKEI 500 Index includes the third largest number of corporations of this industry. Following BW (2004a), a firm-year observation is counted as a payer if it pays positive dividends per share by the ex date; otherwise, it is counted as a nonpayer. For aggregating this firm-level data into useful time series, following BW (2004a), we construct several aggregate identities:

$$
\text { Payers }_{t}=\text { New Payers } \text { Pld Payers }_{t}+\text { List Payers }_{t}
$$

Old Payers $_{t}=$ Payers $_{t-1}-$ New Nonpayers ${ }_{t}-$ Delist Payers $_{t}$.

In the above equations, Payers means the total number of payers, New Payers defines the number of initiators among last year's nonpayers, Old Payers denotes the number of this year's payers that were also payers last year, List Payers means the number of payers this year that were not included in the last year's sample, New Nonpayers defines the number of this year's omitters among last year's payers, and Delist Payers means the number of last year's payers not included in this year's sample. Note that lists and delists are related to the First Section of Tokyo Stock Exchange (TSE).

In order to capture dividend payment dynamics, in accordance with BW (2004a), we then construct following three variables:

$$
\begin{aligned}
& \text { Initiate }_{t}=\text { New } \text { Payers }_{t} /\left(\text { Nonpayers }_{t-1}-\text { Delist Nonpayers }_{t}\right) \\
& \text { Continue }_{t}=\text { Old Payers } t /\left(\text { Payers }_{t-1}-\text { Delist Payers }_{t}\right)
\end{aligned}
$$

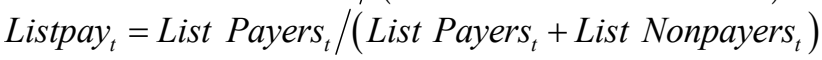

In words, Initiate is the rate of dividend initiation, and this is the ratio of new payers to surviving nonpayers. Next, Continue is the rate at which firms continue dividend paying, and this is the ratio of continuing payers to surviving payers. Finally, Listpay is the rate at which new lists in the sample pay, and this is the ratio of newly listed payers to new lists at time $t$. These variables capture the corporate decision whether to pay dividends, and are not related to the amount of dividends paid.

Table 1 reports the aggregate totals, some dividend payment variables, and payment rates for firms in the Japanese machinery industry. The dividend initiation rate starts out low in 1987, then ups in 1989, and then declines in 1993. After that, it somewhat rebounds in the late 1990s, then drops again in 2002, and then increases towards the end of the sample. The rate at which firms continue paying dividends varies less, as expected. Note that the rate at which lists pay dividends is always high, contrary to the situation of BW (2004a), where Listpay varies significantly. 
Next, we also consider the stock market dividend premium variables. Conceptually, it is meaningful to measure the difference between the market values of firms that have different dividend policies and the same investment policy, since in the efficient and frictionless markets of MM (1961), this market value difference should be zero. However, BW (2004a) suggested that, with limits to arbitrage, the uninformed demand for dividend-paying stocks causes a price difference, and this may vary over time.

We construct the dividend premium variable in accordance with BW (2004a), which is denoted as $P^{D-N D}$. This is the difference between the log of the average value of market-to-book ratios of payers and that of nonpayers. Market-to-book ratios are defined by following Fama and French (FF) (1993, 1996). Namely, the market-to-book ratio is book assets minus book equity plus market equity all divided by book assets.

More concretely, in each year, we take equal- and (book) value-weighted averages of the market-to-book ratios separately for dividend payers and nonpayers. We then construct the final series of dividend premium as the difference of the logs of these averages. These series are shown in Table 2.

Furthermore, we construct other variables for the additional investigations in Section 5. The details of the data and the additional variable constructions are explained in Sections 5.1 and 5.2.

\section{Testing the catering theory}

Our first test is to examine whether catering theory holds in the Japanese machinery industry. That is, our first examination is checking the relationship between companies' dividend payments and the stock market measures of dividend demand. For examining this relation formally, Table 3 regresses the variables of dividend payment on the lagged variables of demand for dividends. More concretely, we perform the following regressions:

$$
\begin{aligned}
& \text { Initiate }_{t}=\mu+\xi P_{t-1}^{D-N D}+\eta_{t}, \\
& \text { Continue }_{t}=\mu+\xi P_{t-1}^{D-N D}+\eta_{t},
\end{aligned}
$$

where Initiate means the rate of dividend initiation, Continue denotes the rate of dividend continuation, and $P^{D-N D}$ means the (value-weighted or equally weighted) market dividend premium. In Table 3, all independent variables are standardized to have unit variance, and all standard errors are robust to serial correlation and heteroskedasticity because the procedure of Newey and West (1987) is used.

Panel A of Table 3 indicates that neither an increase in the value-weighted market dividend premium nor an increase in the equally weighted market dividend premium is related to an increase in the dividend initiation rate in the next year. Similarly, Panel B of Table 3 shows that neither an increase in the value-weighted market dividend premium nor an increase in the equally weighted market dividend premium is related to an increase in the dividend continuation rate in the next year. Namely, contrary to the US evidence in BW (2004a), as far as judged by the dividend premium measures, the dividend policies of the Japanese machinery industry corporations do not cater for investors' demand for dividends.

\section{Additional tests}

\subsection{Cross-sectional tests}

This section further tests the determinants of the dividend payment from the cross-sectional viewpoint. For this purpose, we first apply FF (2001) and BW (2004a)-type logit models. That is, our first cross-sectional test is performed by using the following contemporaneous logit models:

$$
y_{i, t}=\alpha+\vartheta_{1} T S E P_{i, t}+\vartheta_{2}(M / B)_{i, t}+\vartheta_{3}(d A / A)_{i, t}+\vartheta_{4}(E / A)_{i, t}+\tau_{i, t},
$$

where $y_{i, t}=1$ if the firm is a dividend payer and zero otherwise. Further, TSEP is TSE First Section market capitalization percentile (Namely, the percentage of companies on the TSE First Section having smaller capitalization than company $i$ in that year), $M / B$ is the market-to-book ratio, $d A / A$ denotes the total asset growth ratio, and $E / A$ means the after-tax earnings-to-total-asset ratio.

Moreover, to examine the one-year intertemporal relationships, we further estimate the following intertemporal models:

$$
\begin{aligned}
& y_{i, t}=\alpha+\vartheta_{1} T S E P_{i, t-1}+\vartheta_{2}(M / B)_{i, t-1}+\vartheta_{3}(d A / A)_{i, t-1}+\vartheta_{4}(E / A)_{i, t-1}+\tau_{i, t}, \\
& y_{i, t}=\alpha+\vartheta_{1} T S E P_{i, t+1}+\vartheta_{2}(M / B)_{i, t+1}+\vartheta_{3}(d A / A)_{i, t+1}+\vartheta_{4}(E / A)_{i, t+1}+\tau_{i, t},
\end{aligned}
$$

where again $y_{i, t}=1$ if the firm is a dividend payer and zero otherwise.

The most important results are presented in Table 4. Table 4 shows the results of logit models such as (9), and it presents that excluding the period of the stock market crash of 1989 in Japan, the after-tax earnings-to-total-asset ratio is statistically significant with positive sign. Therefore, dividend payers' earnings conditions are well in the 
year prior to paying dividends.

Next, our estimation results of logit models such as (8) indicate that in general, the after-tax earnings-to-total-asset ratio is statistically significant with positive sign. Therefore, the results indicate that the relation between dividend payments and earnings are also strong in the year firms pay dividends. (To save space, we do not display the results as a table.)

Finally, our estimation results of logit models like (10) suggest that again, the after-tax earnings ratio is statistically significant with positive sign in general; however, the significance is lower than in the above previous two cases. (To save space, we do not present the results as a table.) Hence, payers' earnings are also in good conditions in the year after firms pay dividends; however, their financial conditions may be weaker than in the previous two years.

For considering the earnings situations in more detail, we check and present the $p$-values of the coefficients of the $E / A \mathrm{~s}$ in models (8) to (10) in Figure 1. This figure plots the average $p$-values from three sorts of logit models in each year. Since smaller $p$-values are more favorable, we understand that earnings conditions are best in the year before firms pay dividends. Also, we find that earnings conditions are second best in the year they are dividend payers, and worst in the year after firms pay dividends. From these results, from the cross-sectional view point, we consider that the relation between earnings and dividend payments observed in the machinery industry in Japan weakens in the year after their dividend payments.

\subsection{Aggregate time-series tests}

This section additionally examines the dividend policies of the firms of machinery industry in Japan from the aggregate time-series viewpoint. More precisely, both for Initiate and Continue, this section performs alternative intertemporal tests by using several additional variables.

Namely, in addition to the dividend premium variable, $V W P^{D-N D}$ (book value-weighted dividend premium), $V W N o n p a y e r M / B(V W P a y e r M / B)$ denotes the book value-weighted nonpayers' (payers') market-to-book ratios, $V W M / B$ denotes the book value-weighted market-to-book ratios for all firms, $V W D / P$ is all firms' book value-weighted dividend yields, VWSIZE denotes all firms' book value-weighted market capitalization, $V W N o n p a y e r S I Z E$ (VWPayerSIZE) denotes the book value-weighted nonpayers' (payers') market capitalizations, $V W E / A$ is the book value-weighted after-tax earnings-to-total-asset ratios for all firms, VWNonpayerE/A (VWPayerE/A) denotes the book value-weighted nonpayers' (payers') after-tax earnings-to-total-asset ratios, Year means the time trend variable, and Tax means the ratio of after-tax income from dividends relative to after-tax income from capital gains. Thus, the variable Tax indicates the favorability of dividends relative to capital gains from the viewpoint of the Japanese tax system.

We here analyze the relations between dividend payments and the corporate results in the previous year, the contemporaneous relations between dividend payments and corporate results, and the relations between dividend payments and the corporate results in the following year. The above examinations are the extensions of BW (2004a), and these additional investigations explore comprehensively the determinants of dividend policies. First, panel A of Table 5 shows that payers' and nonpayers' market-to-book ratio, all companies' dividend yields, nonpayers' size, and nonpayers' earnings in the previous year are statistically significant determinants of the dividend initiations. Furthermore, panel B of Table 5 presents that payers' market-to-book ratio, all companies' market-to-book ratio, all companies' dividend yields, all companies' size, and payers' size in the previous year are statistically significant determinants of dividend continuations. Therefore, Table 5 demonstrates that many other one-year lagged variables than dividend premium are related with dividend policies of the firms of the machinery industry in Japan.

Second, our empirical results of the contemporaneous relations between dividend payments and corporate results show that payers' and nonpayers' $\mathrm{M} / \mathrm{Bs}$ and payers' earnings in the current year are statistically significant determinants of dividend initiations. In addition, our analysis indicates that all companies' and payers' M/Bs, all firms' dividend yields, and all firms' and payers' earnings in the current year are statistically significant determinants of dividend continuations. (We do not present the results as a table to save space.) Thus, these empirical results again demonstrate that many other variables than dividend premium are contemporaneously connected with the Japanese machinery industry firms' dividend policies.

Further, our empirical results of the relations between dividend payments and the corporate results in the following year show that only payers' earnings ratio in the following period is statistically significant determinant of dividend initiations. Moreover, our analysis indicates that all firms' earnings and payers' earnings in the following year are statistically significant determinants of dividend continuations of the Japanese machinery industry firms. (Again, to save space, we do not display the results as a table.)

The above results mean that from the aggregate time series viewpoint, even if we take into account the intertemporal 
relations, dividend premiums are not determinants of dividend payments Thus, in the Japanese machinery industry, catering behavior among financial managers towards investors' dividend demand is not evident.

\section{Summary and conclusions}

In this paper, we explored the determinants of dividend initiations and continuations in the Japanese machinery industry by considering catering theory. Our empirical investigations derived following interesting new evidence.

(1) First, for the Japanese machinery industry firms, the dividend premium is not a determinant of their dividend initiations and continuations. This implies that, in their dividend policies, firms in the Japanese machinery industry do not behave as the catering theory predicts.

(2) Instead, differently from the US case, with regard to the dividend initiations of the Japanese machinery industry firms, value-weighted payers' and nonpayers' $\mathrm{M} / \mathrm{B}$, value-weighted all companies' dividend yields, value-weighted nonpayers' size, and nonpayers' value-weighted after-tax earnings-to-total-asset ratios are the strong determinants of their one-year-ahead dividend initiations. These are many new findings obtained by our extending research of BW (2004a).

(3) Moreover, contrary to the US case, regarding the dividend continuations of the Japanese machinery industry firms, value-weighted all companies' $M / B$, value-weighted payers' $M / B$, value-weighted all companies' dividend yields and size, and payers' value-weighted size are the strong determinants of their one-year-ahead dividend continuations. These are also much novel evidence derived by our extending investigations.

(4) For the Japanese machinery industry firms, from the cross-sectional viewpoint, we observe the strong relation between corporate earnings and dividend payments in general; however, we find that earnings conditions are best in the year before firms pay dividends, and that earnings conditions are second best in the year they are dividend payers and worst in the year after firms pay dividends. From these results, we suggest that the relation between earnings and dividend payments observed in the machinery industry in Japan weakens in the year after their dividend payments. To sum up, these evidence suggests that we cannot support the signaling hypothesis in the Japanese machinery industry.

As above, the new findings derived in this paper much contribute to the body of researches of dividend policy in the field of corporate finance. Future related works exploiting larger Japanese datasets will be valuable. These works may lead to more comprehensive and stronger conclusions, and this will be our future work.

\section{References}

Allen, F., Bernardo, A. E., \& Welch, I. (2000). A theory of dividends based on tax clienteles. Journal of Finance, 55, 2499-2536. doi:10.1111/0022-1082.00298, http://dx.doi.org/10.1111/0022-1082.00298.

Amihud, Y., Hurvich, C. M., \& Wang, Y. (2009). Multiple-Predictor Regressions: Hypothesis Testing. Review of Financial Studies, 22, 413-434. doi:10.1093/rfs/hhn056, http://dx.doi.org/10.1093/rfs/hhn056.

Asquith, P., \& Mullins, D. W. (1983). The impact of initiating dividend payments on shareholders' wealth. Journal of Business, 56, 77-96. doi:10.1086/296187, http://dx.doi.org/10.1086/296187.

Bagwell, L. S., \& Shoven, J. B. (1989). Cash distributions to shareholders. Journal of Economic Perspectives, 3, 129-140.

Baker, H., Farrelly, K. G. E., \& Edelman, R. B. (1985). A survey of management views on dividend policy. Financial Management, 14, 78-84. doi:10.2307/3665062, http://dx.doi.org/10.2307/3665062.

Baker, M., \& Wurgler, J. A. (2004a). Catering Theory of Dividends. Journal of Finance, 59, 1125-1165. doi:10.1111/j.1540-6261.2004.00658.x, http://dx.doi.org/10.1111/j.1540-6261.2004.00658.x.

Baker, M., \& Wurgler, J. A. (2004b). Appearing and Disappearing Dividends: The Link to Catering Incentives. Journal of Financial Economics, 73, 271-288. doi:10.1016/j.jfineco.2003.08.001, http://dx.doi.org/ 10.1016/j.jfineco.2003.08.001.

Baker, M., Greenwood, R., \& Wurgler, J. (2009). Catering Through Nominal Share Prices. Journal of Finance, 64, 2559-2590. doi:10.1111/j.1540-6261.2009.01511.x, http://dx.doi.org/ 10.1111/j.1540-6261.2009.01511.x.

Benartzi, S., Michaely, R., \& Thaler, R. (1997). Do changes in dividends signal the future or the past? Journal of Finance, 52, 1007-1034. doi:10.1007/s12197-007-9020-4, http://dx.doi.org/ 10.1007/s12197-007-9020-4.

Benerjee, S., Gatchev, V. A., \& Spindt, P. A. (2007). Stock Market Liquidity and Firm Dividend Policy. Journal of Financial and Quantitative Analysis, 42, 369-398. doi:10.1017/S0022109000003318, http://dx.doi.org/10.1017/S0022109000003318. 
Bhattacharya, S. (1979). Imperfect information, dividend policy, and 'the bird in the hand fallacy'. Bell Journal of Economics, 10, 259-270. doi:10.2307/3003330, http://dx.doi.org/10.2307/3003330.

Black, F. (1976). The dividend puzzle. Journal of Portfolio Management, 2, 5-8. doi:10.3905/jpm.1976.408558, http://dx.doi.org/10.3905/jpm.1976.408558.

Black, F., \& Scholes, M. (1974). The effects of dividend yield and dividend policy on common stock prices and returns. Journal of Financial Economics, 1, 1-22. doi:10.1016/0304-405X(74)90006-3, http://dx.doi.org/10.1016/0304-405X(74)90006-3.

Blau, B. M., \& Fuller, K. P. (2008). Flexibility and dividends. Journal of Corporate Finance, 14, 133-152. doi:10.1016/j.jcorpfin.2008.02.003, http://dx.doi.org/10.1016/j.jcorpfin.2008.02.003.

Brav, A., Graham, J. R., Harvey, C. R., \& Michaely, R. (2005). Payout policy in the 21st century. Journal of Financial Economics, 77, 483-527. doi:10.1016/j.jfineco.2004.07.004, http://dx.doi.org/10.1016/j.jfineco.2004.07.004.

Bulan, L., Subramanian, N., \& Tanlu, L. (2007). On the Timing of Dividend Initiations. Financial Management, Winter, 31-65.

Chay J. B., \& Suh J. (2009). Payout policy and cash-flow uncertainty. Journal of Financial Economics, 93, 88-107. doi:10.1016/j.jfineco.2008.12.001, http://dx.doi.org/10.1016/j.jfineco.2008.12.001.

Chen A., \& Lin S. (2011). Asymmetrical return on equity mean reversion and catering. Journal of Banking and Finance, 35, 471-477. doi:10.1016/j.jbankfin.2010.09.009, http://dx.doi.org/10.1016/j.jbankfin.2010.09.009.

Dann, L. Y. (1981). Common stock repurchases: An analysis of returns to bondholders and stockholders. Journal of Financial Economics, 9, 113-138. doi:10.1016/0304-405X(81)90010-6, http://dx.doi.org/10.1016/0304-405X(81)90010-6.

De Angelo, H., De Angelo, L., \& Skinner, D. J. (1996). Reversal of fortune dividend signaling and the disappearance of sustained earnings growth. Journal of Financial Economics, 40, 341-371. doi:10.1016/0304-405X(95)00850-E, http://dx.doi.org/10.1016/0304-405X(95)00850-E.

De Angelo, H., De Angelo, L., \& Stulz, R. M. (2006). Dividend policy and the earned/contributed capital mix: a test of the life-cycle theory. Journal of Financial Economics, 81, 227-254. doi:10.1016/0304-405X(81)90010-6, http://dx.doi.org/10.1016/0304-405X(81)90010-6.

Denis, D. J., \& Osobov, I. (2008). Why do firms pay dividends? International evidence on the determinants of dividend policy. Journal of Financial Economics, 89, 62-82. doi:10.1016/j.jfineco.2007.06.006, http://dx.doi.org/10.1016/j.jfineco.2007.06.006.

Eades, K. M., Hess, P. J., \& Kim, E. H. (1994). Time-series variation in dividend pricing. Journal of Finance, 49, 1617-1638. doi: 10.2307/2329265, http://dx.doi.org/10.2307/2329265.

Eije, H., \& Megginson, W. L. (2008). Dividends and share repurchases in the European Union. Journal of Financial Economics, 89, 347-374. doi:10.1016/j.jfineco.2007.11.002, http://dx.doi.org/10.1016/j.jfineco.2007.11.002.

Fama, E. F., \& Babiak, H. (1968). Dividend policy: An empirical analysis. Journal of the American Statistical Association, 53, 1132-1161. doi:10.2307/2285874, http://dx.doi.org/10.2307/2285874.

Fama, E. F., \& French, K. R. (1993). Common risk factors in the returns on stocks and bonds. Journal of Financial Economics, 33, 3-56. doi:10.1016/0304-405X(93)90023-5, http://dx.doi.org/10.1016/0304-405X(93)90023-5.

Fama, E. F., \& French, K. R. (1996). Multifactor explanations of asset pricing anomalies. Journal of Finance, 51, 55-84. doi: 10.2307/2329302, http://dx.doi.org/10.2307/2329302.

Fama, E. F., \& French, K. R. (2001). Disappearing dividends: Changing firm characteristics or lower propensity to pay? Journal of Financial Economics, 60, 3-43. doi:10.1016/S0304-405X(01)00038-1, http://dx.doi.org/10.1016/S0304-405X(01)00038-1.

Feenberg, D., \& Coutts, E. (1993). An introduction to the Taxsim model. Journal of Policy Analysis and Management, 12, 189-194. doi:10.2307/3325474, http://dx.doi.org/10.2307/3325474.

Graham, J. R., \& Harvey, C. R. (2001). The theory and practice of corporate finance: Evidence from the field. Journal of Financial Economics, 60, 187-243. doi:10.1016/S0304-405X(01)00044-7, http://dx.doi.org/10.1016/S0304-405X(01)00044-7.

Hakansson, N. H. (1982). To pay or not to pay dividends. Journal of Finance, 37, 415-428. doi:10.2307/2327345, http://dx.doi.org/10.2307/2327345. 
Healy, P. M., \& Palepu, K. G. (1988). Earnings information conveyed by dividend initiations and omissions. Journal of Financial Economics, 21, 149-175. doi:10.1016/0304-405X(88)90059-1, http://dx.doi.org/10.1016/0304-405X(88)90059-1.

Hoberg, G., \& Prabhala, N. R. (2009). Disappearing Dividends, Catering, and Risk. Review of Financial Studies, 22, 79-116. doi: 10.1093/rfs/hhn073, http://dx.doi.org/10.1093/rfs/hhn073.

Hubbard, J., \& Michaely, R. (1997). Do investors ignore dividend taxation? A reexamination of the Citizens Utilities case. Journal of Financial and Quantitative Analysis, 32, 117-135. doi:10.2307/2331319, http://dx.doi.org/10.2307/2331319.

John, K., \& Williams, J. (1985). Dividends, dilution, and taxes: A signaling equilibrium. Journal of Finance, 40, 1053-1070. doi: 10.2307/2328394, http://dx.doi.org/10.2307/2328394.

Kothari, S. P., \& Shanken, J. (1997). Book-to-market, dividend yield, and expected market returns: A time series analysis. Journal of Financial Economics, 44, 169-203. doi:10.1016/S0304-405X(97)00002-0, http://dx.doi.org/10.1016/S0304-405X(97)00002-0.

La Porta, R., Lopez-de-Silanes, F., Shleifer, A., \& Vishny, R. (2000). Agency problems and dividend policies around the world. Journal of Finance, 55, 1-33. doi:10.1111/0022-1082.00199, http://dx.doi.org/10.1111/0022-1082.00199.

Li W., \& Lie, E. (2006). Dividend changes and catering incentives. Journal of Financial Economics, 80, 293-308. doi:10.1016/j.jfineco.2005.03.005, http://dx.doi.org/10.1016/j.jfineco.2005.03.005.

Lintner, J. (1956). The distribution of incomes of corporations among dividends, retained earnings, and taxes. American Economic Review, 46, 97-113.

Liu Y., Szewczyk, S. H., \& Zantout, Z. (2008). Underreaction to Dividend Reductions and Omissions? Journal of Finance, 63, 987-1020. doi:10.1111/j.1540-6261.2008.01337.x, http://dx.doi.org/10.1111/j.1540-6261.2008.01337.x.

Long, J. B. (1978). The market valuation of cash dividends: A case to consider. Journal of Financial Economics, 6, 235-264. doi:10.1016/0304-405X(78)90031-4, http://dx.doi.org/10.1016/0304-405X(78)90031-4.

Marsh, T. A., \& Merton, R. C. (1987). Dividend behavior for the aggregate stock market. Journal of Business, 60, $1-40$.

Michaely, R., Thaler, R. H., \& Womack, K. L. (1995). Price reactions to dividend initiations and omissions: Overreaction or drift? Journal of Finance, 50, 573-608. doi:10.2307/2329420, http://dx.doi.org/10.2307/2329420.

Miller, M. H. (1977). Debt and taxes. Journal of Finance, 32, 261-275. doi:10.2307/2326758, http://dx.doi.org/10.2307/2326758.

Miller, M. H., \& Modigliani, F. (1961). Dividend policy, growth and the valuation of shares. Journal of Business, 34, 411-433. doi:10.1086/294442, http://dx.doi.org/10.1086/294442.

Miller, M. H., \& Rock, K. (1985). Dividend policy under asymmetric information. Journal of Finance, 40, 1031-1051. doi:10.2307/2328393, http://dx.doi.org/10.2307/2328393.

Miller, M. H., \& Scholes, M. (1978). Dividends and taxes. Journal of Financial Economics, 6, 333-364. doi:10.1016/0304-405X(78)90009-0, http://dx.doi.org/10.1016/0304-405X(78)90009-0.

Newey, W. K., \& West, K. D. (1987). A simple, positive semi-definite, heteroskedasticity and autocorrelation consistent covariance matrix. Econometrica, 55, 703-708. doi:10.2307/1913610, http://dx.doi.org/10.2307/1913610.

Partington, G. (2009). Discussion of An International Analysis of Dividend Payment Behavior. Journal of Business Finance \& Accounting, 36, 523-529. doi:10.1111/j.1468-5957.2009.02130.x, http://dx.doi.org/10.1111/j.1468-5957.2009.02130.x.

Peterson, P., Peterson, D., \& Ang, J. (1985). Direct evidence on the marginal rate of taxation on dividend income. Journal of Financial Economics, 14, 267-282. doi:10.1016/0304-405X(85)90018-2, http://dx.doi.org/10.1016/0304-405X(85)90018-2.

Poterba, J. M. (1986). The market valuation of cash dividends: The Citizens Utilities case reconsidered. Journal of Financial Economics, 15, 395-405. doi:10.1016/0304-405X(86)90028-0, http://dx.doi.org/10.1016/0304-405X(86)90028-0.

Shefrin, H. M., \& Statman, M. (1984). Explaining investor preference for cash dividends. Journal of Financial Economics, 13, 253-282. doi:10.1016/0304-405X(84)90025-4, http://dx.doi.org/10.1016/0304-405X(84)90025-4.

Shleifer, A. (2000). Inefficient markets: An introduction to behavioral finance. Oxford University Press, Oxford, 
UK.

Stein, J. C. (1989). Efficient capital markets, inefficient firms: A model of myopic corporate behavior. Quarterly Journal of Economics, 104, 655-669. doi:10.2307/2937861, http://dx.doi.org/10.2307/2937861.

Stein, J. C. (1996). Rational capital budgeting in an irrational world. Journal of Business, 69, 429-455. doi:10.1086/209699, http://dx.doi.org/10.1086/209699.

Watts, R. (1973). The information content of dividends. Journal of Business, 46, 191-211. doi:10.1086/295525, http://dx.doi.org/10.1086/295525.

\section{Notes}

Note 1. Important studies that follow and extend MM (1961) are Allen et al. (2000), Amihud et al. (2009), Asquith and Mullins (1983), Bagwell and Shoven (1989), Baker et al. (1985), Baker and Wurgler (2004b), Banerjee et al. (2007), Benartzi et al. (1997), Bhattacharya (1979), Black (1976), Black and Scholes (1974), Blau and Fuller (2008), Brav et al. (2005), Dann (1981), DeAngelo et al. (1996, 2008), Eades et al. (1994), Eije and Magginson (2008), Fama and Babiak (1968), Fama and French (2001), Feenberg and Coutts (1993), Graham and Harvey (2001), Hakansson (1982), Healy and Palepu (1988), Hubbard and Michaely (1997), John and Williams (1985), Kothari and Shanken (1997), La Porta et al. (2000), Lintner (1956), Liu et al. (2008), Long (1978), Marsh and Merton (1987), Michaely et al. (1995), Miller (1977), Miller and Rock (1985), Miller and Scholes (1978), Partington (2009), Peterson et al. (1985), Poterba (1986), Shefrin and Statman (1984), and Watts (1973), for example.

Note 2. In the US, several recent studies discuss this catering theory. Those are such as Baker et al. (2009), Chen and Lin (2011), Li and Lie (2006), and Hoberg and Prabhala (2009). Hoberg and Prabhala (2009) empirically denied the catering effects while other three papers derived the consistent conclusions with catering theory. Not many related researches exist, thus future detailed discussions are expected on this catering theory of dividends.

Note 3. Evidence of inefficient markets was recently presented in studies such as Shleifer (2000) and Stein (1989, 1996).

Table 1. Measures of Dividend Payment

\begin{tabular}{|c|c|c|c|c|c|c|c|c|c|c|c|}
\hline \multirow[b]{2}{*}{ Year } & \multicolumn{4}{|c|}{ Payers } & \multicolumn{4}{|c|}{ Nonpayers } & \multicolumn{3}{|c|}{ Payment Rates (\%) } \\
\hline & Total & New & Old & List & Total & New & Old & List & Initiate & Continue & Listpay \\
\hline 1987 & 69 & 0 & 68 & 1 & 14 & 9 & 5 & 0 & 0.00 & 88.31 & 100.00 \\
\hline 1988 & 68 & 0 & 66 & 2 & 17 & 3 & 14 & 0 & 0.00 & 95.65 & 100.00 \\
\hline 1989 & 76 & 9 & 66 & 1 & 10 & 2 & 8 & 0 & 52.94 & 97.06 & 100.00 \\
\hline 1990 & 86 & 4 & 76 & 6 & 6 & 0 & 6 & 0 & 40.00 & 100.00 & 100.00 \\
\hline 1991 & 88 & 3 & 85 & 0 & 4 & 1 & 3 & 0 & 50.00 & 98.84 & 0.00 \\
\hline 1992 & 91 & 2 & 87 & 2 & 3 & 1 & 2 & 0 & 50.00 & 98.86 & 100.00 \\
\hline 1993 & 85 & 0 & 85 & 0 & 9 & 6 & 3 & 0 & 0.00 & 93.41 & 0.00 \\
\hline 1994 & 79 & 0 & 73 & 6 & 16 & 7 & 9 & 0 & 0.00 & 91.25 & 100.00 \\
\hline 1995 & 71 & 1 & 70 & 0 & 24 & 9 & 15 & 0 & 6.25 & 88.61 & 0.00 \\
\hline 1996 & 73 & 3 & 69 & 1 & 23 & 2 & 21 & 0 & 12.50 & 97.18 & 100.00 \\
\hline 1997 & 77 & 5 & 71 & 1 & 20 & 2 & 18 & 0 & 21.74 & 97.26 & 100.00 \\
\hline 1998 & 85 & 6 & 74 & 5 & 17 & 3 & 14 & 0 & 30.00 & 96.10 & 100.00 \\
\hline 1999 & 79 & 1 & 75 & 3 & 26 & 9 & 16 & 1 & 5.88 & 89.29 & 75.00 \\
\hline 2000 & 85 & 4 & 76 & 5 & 24 & 3 & 21 & 0 & 16.00 & 96.20 & 100.00 \\
\hline 2001 & 93 & 1 & 82 & 10 & 23 & 2 & 21 & 0 & 4.55 & 97.62 & 100.00 \\
\hline 2002 & 86 & 0 & 84 & 2 & 31 & 9 & 22 & 0 & 0.00 & 90.32 & 100.00 \\
\hline 2003 & 87 & 3 & 83 & 1 & 29 & 2 & 27 & 0 & 10.00 & 97.65 & 100.00 \\
\hline 2004 & 92 & 8 & 81 & 3 & 23 & 2 & 21 & 0 & 27.59 & 97.59 & 100.00 \\
\hline 2005 & 102 & 7 & 90 & 5 & 16 & 0 & 16 & 0 & 30.43 & 100.00 & 100.00 \\
\hline 2006 & 110 & 6 & 99 & 5 & 10 & 0 & 10 & 0 & 37.50 & 100.00 & 100.00 \\
\hline
\end{tabular}

Notes: A firm is defined as a dividend payer at time $t$ if it pays positive dividends per share by the ex date. A firm is defined as a new dividend payer at time $t$ if it pays positive dividends per share by the ex date at time $t$ and zero dividends at time $t-1$. A firm is defined as an old payer at time $t$ if it pays positive dividends per share by the ex date at time $t$ and at time $t-1$. A firm is defined as a new list payer if it pays positive dividends per share by the ex date at time $t$ and is not in the sample at time $t-1$. A firm is defined as a nonpayer at time $t$ if it does not have pay dividends per share by the ex date. New nonpayers are firms who were payers at time $t-1$ but not at $t$. Old nonpayers are firms who were nonpayers in both $t-1$ and $t$. New list nonpayers are nonpayers at time $t$ that were not in the sample at $t-1$. The initiation rate Initiate denotes payers as a percentage of surviving nonpayers from $t-1$. The rate at which firms continue paying dividends Continue denotes payers as a percentage of surviving payers from $t-1$. The rate at which lists pay Listpay denotes payers as a percentage of new lists at time $t$. 
Table 2. The Market Dividend Premium Measures

\begin{tabular}{|c|c|c|c|c|c|c|}
\hline \multirow[b]{2}{*}{ Year } & \multicolumn{2}{|c|}{ Payers } & \multicolumn{2}{|c|}{ Nonpayers } & \multicolumn{2}{|c|}{ Dividend Premium $\left(P^{D-N D}\right)$} \\
\hline & EWM/B & VWM/B & EWM/B & VWM/B & EW & VW \\
\hline 1986 & 1.50 & 1.37 & 1.30 & 1.21 & 14.44 & 11.98 \\
\hline 1987 & 1.50 & 1.38 & 1.54 & 1.41 & -2.55 & -2.51 \\
\hline 1988 & 1.88 & 1.69 & 1.92 & 1.80 & -2.58 & -6.07 \\
\hline 1989 & 2.18 & 2.13 & 2.28 & 2.05 & -4.37 & 3.69 \\
\hline 1990 & 2.37 & 2.12 & 2.53 & 2.10 & -6.38 & 1.37 \\
\hline 1991 & 1.95 & 1.82 & 2.09 & 2.12 & -6.71 & -15.15 \\
\hline 1992 & 1.52 & 1.42 & 1.46 & 1.48 & 3.55 & -4.32 \\
\hline 1993 & 1.42 & 1.37 & 1.35 & 1.35 & 4.85 & 1.52 \\
\hline 1994 & 1.49 & 1.44 & 1.40 & 1.37 & 6.00 & 5.59 \\
\hline 1995 & 1.34 & 1.32 & 1.37 & 1.32 & -2.04 & 0.25 \\
\hline 1996 & 1.57 & 1.57 & 1.66 & 1.52 & -5.45 & 2.74 \\
\hline 1997 & 1.35 & 1.42 & 1.28 & 1.21 & 5.19 & 16.30 \\
\hline 1998 & 1.14 & 1.24 & 1.08 & 1.00 & 5.93 & 20.64 \\
\hline 1999 & 1.15 & 1.20 & 1.10 & 1.05 & 4.14 & 13.69 \\
\hline 2000 & 1.46 & 1.32 & 1.06 & 1.00 & 31.52 & 27.76 \\
\hline 2001 & 1.18 & 1.19 & 0.99 & 1.01 & 17.86 & 15.78 \\
\hline 2002 & 1.18 & 1.20 & 0.94 & 0.94 & 22.41 & 24.62 \\
\hline 2003 & 0.99 & 1.03 & 0.91 & 0.91 & 7.65 & 13.08 \\
\hline 2004 & 1.23 & 1.25 & 1.18 & 1.14 & 3.86 & 8.78 \\
\hline 2005 & 1.32 & 1.30 & 1.26 & 1.13 & 4.98 & 13.88 \\
\hline 2006 & 1.71 & 1.80 & 1.56 & 1.38 & 9.52 & 26.09 \\
\hline
\end{tabular}

Notes: A firm is defined as a dividend payer at time $t$ if it pays positive dividends per share by the ex date. A firm is defined as a nonpayer at time $t$ if it does not have pay dividends per share by the ex date. The market-to-book ratio is the ratio of the market value of the firm to its book value. The market-to-book ratio shown is an equal-weighed (EW) or value-weighted (VW) average, by book value across dividend payers and nonpayers. These ratios are computed for the entire sample and for new lists. A firm is defined as a new list if it is not in the sample at time $t-1$. The dividend premium $P^{D-N D}$ means the difference between the logs of the dividend payers' and nonpayers' average market-to-book ratios.

Table 3. Dividend Payment and Demand for Dividends: Testing the Catering Theory

\begin{tabular}{|c|c|c|c|c|}
\hline & \multicolumn{2}{|c|}{ Panel A: Initiate $_{t}$} & \multicolumn{2}{|c|}{ Panel B: Continue $_{t}$} \\
\hline \multirow{2}{*}{$\mathrm{VW} P^{D-N D}{ }_{t-1}$} & $-7.31^{*}$ & & -0.58 & \\
\hline & {$[0.06]$} & & {$[0.38]$} & \\
\hline \multirow{2}{*}{$\mathrm{EW} P^{D-N D}{ }_{t-1}$} & & $-1.03 * *$ & & -0.11 \\
\hline & & {$[0.01]$} & & {$[0.22]$} \\
\hline$N$ & 20 & 20 & 20 & 20 \\
\hline $\operatorname{Adj} . R^{2}$ & 0.09 & 0.26 & -0.03 & 0.03 \\
\hline
\end{tabular}

Notes: Regressions of dividend initiation and continuation rates on measures of the dividend premium. For example, the initiation rate is modeled in Panel A as: Initiate $_{t}=\mu+\xi P^{D-N D}{ }_{t-1}+\eta_{t}$.

The initiation rate Initiate denotes payers as a percentage of surviving nonpayers from $t-1$. The continuation rate Continue denotes payers as a percentage of surviving payers from $t-1$. The dividend premium $P^{D-N D}$ is the difference between the $\operatorname{logs}$ of the EW and VW market-to-book ratios for dividend payers and nonpayers. The independent variables are standardized to have unit variance. $p$-values in [ ] are robust to heteroskedasticity and serial correlation since the method of Newey and West (1987) is used. $N$ is the number of sample and Adj. $R^{2}$ is the adjusted $R$-squared value. * means statistical significance at the $10 \%$ level and ** means statistical significance at the $5 \%$ level. 
Table 4. Cross-sectional Determinants on Dividend Payments in the Following Year

\begin{tabular}{|c|c|c|c|c|c|c|}
\hline & $\mathrm{TSEP}_{t-1}$ & $\mathrm{M} / \mathrm{B}_{t-1}$ & $\mathrm{dA} / \mathrm{A}_{t-1}$ & $\mathrm{E} / \mathrm{A}_{t-1}$ & $N$ & McFadden $R$-squared \\
\hline \multirow[t]{3}{*}{1987} & $0.022[0.124]$ & & & $1.401 * *[0.000]$ & 82 & 0.402 \\
\hline & & $-0.620[0.256]$ & & $1.648 * *[0.001]$ & 82 & 0.381 \\
\hline & & & $0.088[0.085]$ & $1.366 *[0.001]$ & 82 & 0.413 \\
\hline \multirow[t]{3}{*}{1988} & $0.018[0.191]$ & & & $2.197 * *[0.005]$ & 83 & 0.692 \\
\hline & & $-0.052[0.952]$ & & $2.246 *[0.003]$ & 83 & 0.680 \\
\hline & & & $0.028[0.299]$ & $2.142 *[0.006]$ & 83 & 0.685 \\
\hline \multirow[t]{3}{*}{1989} & $0.010[0.521]$ & & & $0.461[0.107]$ & 85 & 0.200 \\
\hline & & $0.346[0.648]$ & & $0.501[0.093]$ & 85 & 0.194 \\
\hline & & & $0.142 *[0.027]$ & $0.383[0.271]$ & 85 & 0.342 \\
\hline \multirow[t]{3}{*}{1990} & $0.037 *[0.043]$ & & & $0.989 *[0.000]$ & 86 & 0.470 \\
\hline & & $-0.609[0.087]$ & & $0.929 * *[0.001]$ & 86 & 0.429 \\
\hline & & & $0.146 *[0.019]$ & $0.667 * *[0.002]$ & 86 & 0.490 \\
\hline \multirow[t]{3}{*}{1991} & $0.032[0.119]$ & & & $1.381 *[0.016]$ & 92 & 0.398 \\
\hline & & $-0.477[0.145]$ & & $1.173 *[0.021]$ & 92 & 0.352 \\
\hline & & & $0.023[0.754]$ & $1.068[0.092]$ & 92 & 0.342 \\
\hline \multirow[t]{3}{*}{1992} & $0.019[0.592]$ & & & $2.007 *[0.024]$ & 92 & 0.593 \\
\hline & & $2.907[0.295]$ & & $2.623 * *[0.007]$ & 92 & 0.608 \\
\hline & & & $0.153[0.164]$ & $0.615 * *[0.001]$ & 92 & 0.660 \\
\hline \multirow[t]{3}{*}{1993} & $0.021[0.272]$ & & & $0.468 *[0.020]$ & 94 & 0.319 \\
\hline & & $1.539[0.391]$ & & $0.531 * *[0.005]$ & 94 & 0.303 \\
\hline & & & $0.005[0.926]$ & $0.522 *[0.012]$ & 94 & 0.289 \\
\hline \multirow[t]{3}{*}{1994} & $0.021[0.059]$ & & & $0.629 * *[0.000]$ & 89 & 0.570 \\
\hline & & $1.745[0.417]$ & & $0.652 * *[0.000]$ & 89 & 0.560 \\
\hline & & & $0.063[0.339]$ & $0.600 * *[0.000]$ & 89 & 0.561 \\
\hline \multirow[t]{3}{*}{1995} & $0.018[0.184]$ & & & $0.767 * *[0.000]$ & 95 & 0.483 \\
\hline & & $0.428[0.719]$ & & $0.783 * *[0.002]$ & 95 & 0.462 \\
\hline & & & $-0.034[0.340]$ & $0.839 * *[0.001]$ & 95 & 0.471 \\
\hline \multirow[t]{3}{*}{1996} & $0.011[0.335]$ & & & $0.422 * *[0.003]$ & 95 & 0.328 \\
\hline & & $-0.866[0.328]$ & & $0.459 * *[0.001]$ & 95 & 0.323 \\
\hline & & & $-0.039[0.391]$ & $0.503 * * 0.003]$ & 95 & 0.327 \\
\hline \multirow[t]{3}{*}{1997} & $0.019[0.165]$ & & & $0.456[0.069]$ & 96 & 0.345 \\
\hline & & $-1.189[0.110]$ & & $0.534 *[0.021]$ & 96 & 0.339 \\
\hline & & & $-0.065[0.075]$ & $0.612 *[0.023]$ & 96 & 0.341 \\
\hline \multirow[t]{3}{*}{1998} & $0.029 *[0.044]$ & & & $0.649 * *[0.005]$ & 97 & 0.375 \\
\hline & & $-2.073[0.065]$ & & $0.880 * *[0.001]$ & 97 & 0.345 \\
\hline & & & $0.068[0.159]$ & $0.726 * *[0.003]$ & 97 & 0.348 \\
\hline \multirow[t]{3}{*}{1999} & $0.035 *[0.024]$ & & & $0.381 *[0.032]$ & 101 & 0.328 \\
\hline & & $-0.212[0.784]$ & & $0.561 *[0.011]$ & 101 & 0.248 \\
\hline & & & $-0.051[0.184]$ & $0.584 * *[0.004]$ & 101 & 0.257 \\
\hline \multirow[t]{3}{*}{2000} & $0.037 * *[0.000]$ & & & $0.158 *[0.014]$ & 104 & 0.220 \\
\hline & & $-0.031[0.935]$ & & $0.204 *[0.038]$ & 104 & 0.093 \\
\hline & & & $0.098 *[0.013]$ & $0.151[0.125]$ & 103 & 0147 \\
\hline \multirow{3}{*}{2001} & $0.029 * *[0.008]$ & & & $0.204 *[0.001]$ & 106 & 0.225 \\
\hline & & $0.069[0.777]$ & & $0.217 *[0.000]$ & 106 & 0.149 \\
\hline & & & $-0.018[0.431]$ & $0.232 * *[0.000]$ & 106 & 0.156 \\
\hline 2002 & $0.024 * *[0.005]$ & & & $0.250 * *[0.003]$ & 115 & 0.213 \\
\hline & & $-0.047[0.918]$ & & $0.295 * *[0.001]$ & 115 & 0.156 \\
\hline & & & $-0.022[0.265]$ & $0.316 * *[0.000]$ & 115 & 0.163 \\
\hline 2003 & $0.049 * *[0.000]$ & & & $0.104 *[0.024]$ & 115 & 0.307 \\
\hline & & $1.478[0.060]$ & & $0.144 * *[0.010]$ & 115 & 0.145 \\
\hline & & & $-0.025[0.409]$ & $0.173 *[0.016]$ & 115 & 0.122 \\
\hline 2004 & $0.037 * *[0.008]$ & & & $0.241 *[0.033]$ & 112 & 0.315 \\
\hline & & $-0.427[0.433]$ & & $0.294 * *[0.005]$ & 112 & 0.217 \\
\hline & & & $0.048[0.210]$ & $0.248 * *[0.010]$ & 112 & 0.228 \\
\hline 2005 & $0.031[0.055]$ & & & $0.116 *[0.039]$ & 113 & 0.249 \\
\hline & & $-0.123[0.756]$ & & $0.163 * *[0.005]$ & 113 & 0.181 \\
\hline & & & $0.023[0.506]$ & $0.140 *[0.021]$ & 112 & 0.187 \\
\hline 2006 & $0.064[0.063]$ & & & $0.574 * *[0.001]$ & 115 & 0.492 \\
\hline & & $-0.770[0.249]$ & & $0.515 * *[0.000]$ & 115 & 0.336 \\
\hline & & & $0.005[0.823]$ & $0.498 * *[0.000]$ & 114 & 0.332 \\
\hline
\end{tabular}

Notes: Cross-sectional logit models are estimated. For example, the estimated logit model is as follows:

$y_{i, t}=\alpha+\theta_{1} T S E P_{i, t-1}+\theta_{2}(M / B)_{i, t-1}+\theta_{3}(d A / A)_{i, t-1}+\theta_{4}(E / A)_{i, t-1}+\tau_{i, t}$,

where $y_{i, t}=1$ if the company is a payer and zero otherwise. In addition, TSEP denotes Tokyo Stock Exchange (TSE) First Section market capitalization percentile, namely, the percentage of firms on the TSE First Section having smaller capitalization than firm $i$ in that year, $M / B$ is the market-to-book ratio, $d A / A$ is the total asset growth ratio, and $E / A$ denotes the after-tax earnings-to-total-asset ratio. ** denotes the statistical significance of the coefficients at the $1 \%$ level, and * denotes the statistical significance of the coefficients at the $5 \%$ level, respectively. 
Table 5. Determinants on the Following Year's Dividend Payments

\begin{tabular}{|c|c|c|c|c|c|c|c|c|c|c|}
\hline \multicolumn{11}{|c|}{ Panel A: Initiate $_{t}$} \\
\hline $\mathrm{VW} P_{t-1}^{D-N D}$ & $\begin{array}{l}-5.73 \\
{[0.17]}\end{array}$ & & & & & & & & & \\
\hline VW Payer $M / B_{t-1}$ & & $\begin{array}{c}16.47 * * \\
{[0.00]}\end{array}$ & & & & & & & & \\
\hline $\mathrm{VW}$ Nonpayer $M / B_{t-1}$ & & & $\begin{array}{c}20.79 * * \\
{[0.00]}\end{array}$ & & & & & & $\begin{array}{c}17.50^{* *} \\
{[0.00]}\end{array}$ & \\
\hline $\mathrm{VW} D / P_{t-1}$ & & & & $\begin{array}{c}-8.45^{*} \\
{[0.03]}\end{array}$ & & & & & $\begin{array}{c}2.21 \\
{[0.41]}\end{array}$ & $\begin{array}{c}-5.49 \\
{[0.124]}\end{array}$ \\
\hline VW Payer SIZE $E_{t-1}$ & & & & & $\begin{array}{c}9.84 \\
{[0.08]}\end{array}$ & & & & & \\
\hline $\mathrm{VW}$ Nonpayer SIZE $E_{t-1}$ & & & & & & $\begin{array}{c}11.93 * * \\
{[0.01]}\end{array}$ & & & & $\begin{array}{c}1.94 \\
{[0.58]}\end{array}$ \\
\hline VW Payer $E / A_{t-1}$ & & & & & & & $\begin{array}{c}6.67 \\
{[0.20]}\end{array}$ & & & \\
\hline $\mathrm{VW}$ Nonpayer $E / A_{t-1}$ & & & & & & & & $\begin{array}{c}12.19^{* *} \\
{[0.00]}\end{array}$ & $\begin{array}{l}8.37 * * \\
{[0.00]}\end{array}$ & $\begin{array}{c}10.42 * * \\
{[0.00]}\end{array}$ \\
\hline $\operatorname{Tax}_{t-1}$ & $\begin{array}{l}10.38 \\
{[0.07]}\end{array}$ & $\begin{array}{c}4.66 \\
{[0.53]}\end{array}$ & $\begin{array}{l}-0.34 \\
{[0.97]}\end{array}$ & $\begin{array}{l}11.64 * \\
{[0.05]}\end{array}$ & $\begin{array}{c}14.69^{* *} \\
{[0.00]}\end{array}$ & $\begin{array}{c}5.61 \\
{[0.34]}\end{array}$ & $\begin{array}{l}10.20 \\
{[0.09]}\end{array}$ & $\begin{array}{c}16.00^{* *} \\
{[0.00]}\end{array}$ & $\begin{array}{c}3.84 \\
{[0.48]}\end{array}$ & $\begin{array}{c}12.61^{* *} \\
{[0.01]}\end{array}$ \\
\hline Year $_{t-1}$ & $\begin{array}{c}0.83 \\
{[0.50]}\end{array}$ & $\begin{array}{c}1.00 \\
{[0.42]}\end{array}$ & $\begin{array}{c}2.36 \\
{[0.15]}\end{array}$ & $\begin{array}{l}-0.94 \\
{[0.22]}\end{array}$ & $\begin{array}{c}-2.83 * * \\
{[0.00]}\end{array}$ & $\begin{array}{l}-0.01 \\
{[0.10]}\end{array}$ & $\begin{array}{l}-0.92 \\
{[0.45]}\end{array}$ & $\begin{array}{c}-2.28 * * \\
{[0.00]}\end{array}$ & $\begin{array}{c}1.17 \\
{[0.24]}\end{array}$ & $\begin{array}{l}-1.30 \\
{[0.11]}\end{array}$ \\
\hline$N$ & 20 & 20 & 20 & 20 & 20 & 20 & 20 & 20 & 20 & 20 \\
\hline $\operatorname{Adj} . R^{2}$ & 0.14 & 0.51 & 0.59 & 0.29 & 0.24 & 0.41 & 0.18 & 0.60 & 0.77 & 0.66 \\
\hline \multicolumn{11}{|c|}{ Panel B: Continue ${ }_{t}$} \\
\hline $\mathrm{VW} P_{t-1}^{D-N D}$ & $\begin{array}{l}-1.24 \\
{[0.38}\end{array}$ & & & & & & & & & \\
\hline $\mathrm{VW} M / B_{t-1}$ & & $\begin{array}{l}2.97^{* *} \\
{[0.00]}\end{array}$ & & & & & & & $\begin{array}{l}3.88^{*} \\
{[0.03]}\end{array}$ & \\
\hline VW Payer $M / B_{t-1}$ & & & $\begin{array}{l}2.86^{* *} \\
{[0.00]}\end{array}$ & & & & & & $\begin{array}{c}0.94 \\
{[0.47]}\end{array}$ & \\
\hline $\mathrm{VW} D / P_{t-1}$ & & & & $\begin{array}{c}-1.40^{* *} \\
{[0.01]}\end{array}$ & & & & & & $\begin{array}{l}-0.79 \\
{[0.15]}\end{array}$ \\
\hline VW $S_{Z Z E_{t-1}}$ & & & & & $\begin{array}{l}2.44 * * \\
{[0.00]}\end{array}$ & & & & & \\
\hline VW Payer SIZE $E_{t-1}$ & & & & & & $\begin{array}{l}2.42^{* *} \\
{[0.00]}\end{array}$ & & & & $\begin{array}{l}1.95^{*} \\
{[0.04]}\end{array}$ \\
\hline $\mathrm{VW} E / A_{t-1}$ & & & & & & & $\begin{array}{c}0.23 \\
{[0.89]}\end{array}$ & & & \\
\hline VW Payer $E / A_{t-1}$ & & & & & & & & $\begin{array}{c}0.11 \\
{[0.95]}\end{array}$ & & \\
\hline $\operatorname{Tax}_{t-1}$ & $\begin{array}{c}1.53 \\
{[0.33]}\end{array}$ & $\begin{array}{c}0.59 \\
{[0.57]}\end{array}$ & $\begin{array}{c}0.70 \\
{[0.49]}\end{array}$ & $\begin{array}{l}1.93 * \\
{[0.04]}\end{array}$ & $\begin{array}{l}2.49 * * \\
{[0.01]}\end{array}$ & $\begin{array}{l}2.72 * * \\
{[0.01]}\end{array}$ & $\begin{array}{c}2.24 \\
{[0.18]}\end{array}$ & $\begin{array}{c}2.31 \\
{[0.19]}\end{array}$ & $\begin{array}{c}0.40 \\
{[0.72]}\end{array}$ & $\begin{array}{l}2.40^{*} \\
{[0.02]}\end{array}$ \\
\hline Year $_{t-1}$ & $\begin{array}{c}0.10 \\
{[0.80]}\end{array}$ & $\begin{array}{l}0.41^{*} \\
{[0.05]}\end{array}$ & $\begin{array}{c}0.37 \\
{[0.06]}\end{array}$ & $\begin{array}{c}0.03 \\
{[0.84]}\end{array}$ & $\begin{array}{c}-0.30^{*} \\
{[0.02]}\end{array}$ & $\begin{array}{c}-0.36^{* *} \\
{[0.00]}\end{array}$ & $\begin{array}{l}-0.10 \\
{[0.79]}\end{array}$ & $\begin{array}{l}-0.11 \\
{[0.77]}\end{array}$ & $\begin{array}{c}0.45 \\
{[0.06]}\end{array}$ & $\begin{array}{c}-0.23^{*} \\
{[0.03]}\end{array}$ \\
\hline$N$ & 20 & 20 & 20 & 20 & 20 & 20 & 20 & 20 & 20 & 20 \\
\hline $\operatorname{Adj} \cdot R^{2}$ & 0.09 & 0.34 & 0.33 & 0.17 & 0.24 & 0.24 & 0.05 & 0.05 & 0.30 & 0.23 \\
\hline
\end{tabular}

Notes: Several regressions of dividend payment rates on measures of the dividend premium and other nominated variables are performed. For example, the initiation rate is modeled in Panel A as:

Initiate $_{t}=\alpha+\theta_{1} V W P^{D-N D}{ }_{t-1}+\theta_{2} V W N$ onpayerM/B $B_{t-1}+\theta_{3} V W D / P_{t-1}$

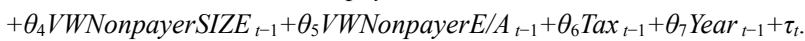

The initiation rate Initiate denotes payers as a percentage of surviving nonpayers from $t-1$. The continuation rate Continue denotes payers as a percentage of surviving payers from $t-1$. All independent variables but Year are standardized to unit variance. Since $p$-values are derived by the method of Newey and West (1987), they are robust to heteroskedasticity and serial correlation. ${ }^{* *}$ denotes the statistical significance of the coefficients at the $1 \%$ level, and * denotes the statistical significance of the coefficients at the $5 \%$ level, respectively. $N$ is the number of sample and $A d j . R^{2}$ is the adjusted $R$-squared value. 


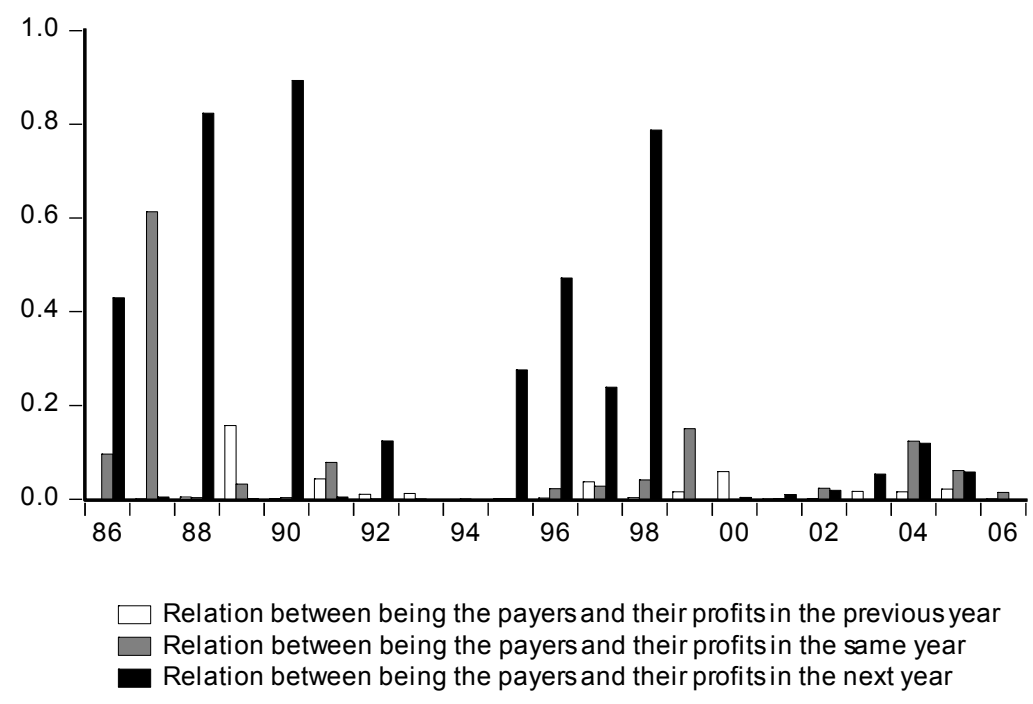

Figure 1. Statistical Significance of the Earnings-to-Asset Ratios for the Dividend Payments

Average $p$-values of the coefficients of $E / A$ from three kinds of logit models are plotted from 1986 to 2006 . For example, for deriving $p$-values as to the contemporaneous relations between firms' dividend payments and their after-tax earnings-to-total-asset ratios, three estimated models are as follows: (1) $y_{i, t}=\alpha+\theta_{1} T S E P_{i, t}+\theta_{2}(E / A)_{i, t}+\tau_{i, t}$, (2) $y_{i, t}=\alpha+\theta_{1}(M / B)_{i, t}+\theta_{2}(E / A)_{i, t}+\tau_{i, t}$, and (3) $y_{i, t}=\alpha+\theta_{1}(d A / A)_{i, t}+\theta_{2}(E / A)_{i, t}+\tau_{i, t}$. 